\title{
Protein Elicitor PemG1 from Magnaporthe grisea Induces Systemic Acquired Resistance (SAR) in Plants
}

\author{
Dong-Hai Peng, ${ }^{1}$ De-Wen Qiu, ${ }^{2}$ Li-Fang Ruan, ${ }^{1}$ Chen-Fei Zhou, ${ }^{1}$ and Ming Sun ${ }^{1}$ \\ ${ }^{1}$ State Key Laboratory of Agricultural Microbiology, College of Life Science and Technology, Huazhong Agricultural University, \\ Wuhan 430070, China; ${ }^{2}$ Institute of Plant Protection of Chinese Academy of Agricultural Sciences, Beijing 100081, China
}

Submitted 7 January 2011. Accepted 20 June 2011.

\begin{abstract}
Elicitors can stimulate defense responses in plants and have become a popular strategy in plant disease control. Previously, we isolated a novel protein elicitor, PemG1, from Magnaporthe grisea. In the present study, PemG1 protein expressed in and purified from Escherichia coli improved resistance of rice and Arabidopsis to bacterial infection, induced transient expression of pathogenesisrelated $(P R)$ genes, and increased accumulation of hydrogen peroxide in rice. The effects of PemG1 on disease resistance and $P R$ gene expression were mobilized systemically throughout the rice plant and persisted for more than 28 days. PemG1-induced accumulation of $O s P R-1 a$ in rice was prevented by the calcium channel blockers $\mathrm{LaCl}_{3}$, BAPTA, EGTA, W7, and TFP. Arabidopsis mutants that are insensitive to jasmonic acid (JA) and ethylene showed increased resistance to bacterial infection after PemG1 treatment but PemG1 did not affect resistance of mutants with an impaired salicylic acid (SA) transduction pathway. In rice, PemG1 induced overexpressions of the SA signal-related genes (OsEDS1, OsPAL1, and OsNH1) but not the JA pathway-related genes (OsLOX2 and OsAOS2). Our findings reveal that PemG1 protein can function as an activator of plant disease resistance, and the PemG1-mediated systemic acquired resistance is modulated by $\mathrm{SA}$ - and $\mathrm{Ca}^{2+}$-related signaling pathways.
\end{abstract}

Plants are continually exposed to attacks by various pathogens, including fungi, bacteria, and viruses. During such interactions, plants respond to pathogenic attacks through various defenses, including constitutive chemical or mechanical barriers. They also develop some effective induced defense mechanisms, such as the hypersensitive reaction (HR) - a local cell death response at the site of infection that cordons off the pathogen and limits its spread (Allen et al. 2004; Mansfield 2009; Rowland et al. 2005; Shen et al. 2003) —and systemic acquired resistance (SAR). SAR is generally triggered by pathogeninduced localized cell death. It can spread throughout the entire plant and induces long-lasting, efficient resistance against a broad spectrum of pathogens (Durrant and Dong 2004; Mansfield 2009; Vlot et al. 2008). In plant-microbe interactions, many pathogenic microorganisms produce one or more protein elicitors, which can trigger the induction of these defense responses in plants.

Corresponding author: M. Sun; Telephone: 86-27-87283455; Fax: 86-2787280670,E-mail: m98sun@mail.hzau.edu.cn

* The $e$-Xtra logo stands for "electronic extra" and indicates that one supplementary figure is published online and Figures 1 and 5 appear in color online.
Many protein elicitors have been isolated and used to improve the pathogen resistance of plants. For example, harpins were first isolated from Erwinia amylovora (Wei et al. 1992) and have been shown to elicit the HR and induce disease resistance in many plants (Adam et al. 1997; Kvitko et al. 2007; Wei et al. 1992). Harpins have been reported from many bacterial plant pathogens and their encoding genes have been isolated (Adam et al. 1997; Ahmad et al. 2001; He et al. 1993; Kvitko et al. 2007; Oh et al. 2007). They are glycine-rich proteins that lack cysteine, and they are secreted in culture when the Hrp system is expressed. They show heat-stable HR elicitor activity when infiltrated into the leaves of tobacco and several other plants (Alfano and Collmer 1997; Oh et al. 2007). A biopreparation known as "Messenger" was develop using harpins; this system has been used successfully in many plants to elicit plant disease resistance; to promote growth, yield, and quality; and even to promote resistance to insects (Shao et al. 2008).

Another family of protein elicitors, the elicitins, is produced by many pathogenic fungi (Phytophthora cryptogea, $P$. megasperma, $P$. nicotianae, and $P$. palmivora). They can also induce disease resistance in some plants (Osman et al. 2001a; Vauthrin et al. 1999; Yu 1995). These protein elicitors are small $(10 \mathrm{kDa})$, hydrophilic, secreted proteins, and are classified as sterol carrier proteins because some exhibit sterol and lipid carrier activity in vitro (Osman et al. 2001b; Vauthrin et al. 1999; Yousef et al. 2009). Elicitins are encoded by a large multigene family that is divided into at least eight different classes based on sequence homology and protein motif diversity (Jiang et al. 2006). Tobacco plants treated with elicitins showed enhanced resistance to infection challenge by Tobacco mosaic virus (Keller et al. 1999). Like harpins, elicitins have also been used in a biopreparation and have been expressed in transgenic plants to confer disease resistance (Yousef et al. 2009).

With the discovery of protein elicitors, there has been great interest in manipulating the inducible responses of plants for crop protection. Searching for novel protein elicitors has become a popular strategy in plant disease control (Mishra et al. 2009; Zhang et al. 2010). Previously, we purified a novel protein elicitor named PemG1 from Magnaporthe grisea (GenBank accession number: EF062504). PemG1 is a $36-\mathrm{kDa}$ (pI 4.7), heat-stable protein. It can increase the resistance of rice to the blast fungus $M$. grisea. Physiological and biochemical studies revealed that PemG1 treatment increased the activities of cellulase and alcohol dehydrogenase in several crops, and increased the contents of both hydrogen peroxide and proline. Introduction of the coding gene pemG1 into the 'Nipponbare' rice yielded transformants with enhanced resistance to rice blast disease (Qiu et al. 2009).

The aim of this study was to clarify the mechanisms by which PemG1 induces resistance in plants. Our results show 
that the purified PemG1 protein can function as a defense activator to induce SAR-like disease resistance in plants. We further demonstrated that the PemG1-mediated SAR is modulated by salicylic acid (SA)- and $\mathrm{Ca}^{2+}$-related signaling pathways, and that hydrogen peroxide has an important role. Our findings reveal the mode of action of the novel protein elicitor PemG1. This could provide a novel strategy for the control of plant disease.

\section{RESULTS}

\section{PemG1 induces disease resistance in rice.}

The GST-PemG1 fusion protein was expressed in Escherichia coli and purified (Supplementary Fig. S1A and B, respectively). To obtain PemG1 protein, GST-PemG1 protein was purified using GST-affinity chromatography and, afterward, the GST tag was removed from GST-PemG1 using PreScission protease.

To evaluate the ability of PemG1 to activate plant defense, PemG1-treated rice plants ('Nakdong') were inoculated with the compatible bacterial leaf blight pathogen Xanthomonas oryzae pv. oryzae PXO61. In control rice plants, typical blight symptoms were clearly visible at $48 \mathrm{~h}$ after inoculation, and began to spread along the vascular system. On leaves that had been treated with PemG1 at $50 \mathrm{ng} / \mathrm{ml}$, the inoculated, clipped sites rapidly changed to a dark-brown color within $36 \mathrm{~h}$ after inoculation, and the disease did not progress further thereafter (Fig. 1A). PemG1 also protected the Arabidopsis ecotype Columbia-0 (Col-0) against infection with the virulent Pseudomonas syringae pv. tomato DC 3000 (Fig. 1B).

The effects of PemG1 on the growth of PXO61 and DC 3000 were determined in vitro by growing the pathogen on agar cultures supplemented with purified PemG1 from 1 to 5 days. The growth of the pathogens was comparable between the PemG1 treatment and the control (Fig. 1C and D), suggest- ing that PemG1 protects plants against bacterial pathogens by inducing plant resistance, not by directly restricting pathogen growth.

\section{PemG1 induces transient expression of pathogenesis-related genes.}

To understand the mechanisms involved in PemG1-induced resistance in rice, we first analyzed the expression patterns of two rice pathogenesis-related $(P R)$ genes: $O s P R-1 a$ (a gene encoding PR protein 1) and OSPR-10a (a probenazole-inducible gene encoding intracellular PR-10) (Hwang et al. 2008; Mitsuhara et al. 2008). Inoculation of Nakdong rice with the virulent $X$. oryzae pv. oryzae PXO61 induced the expression of

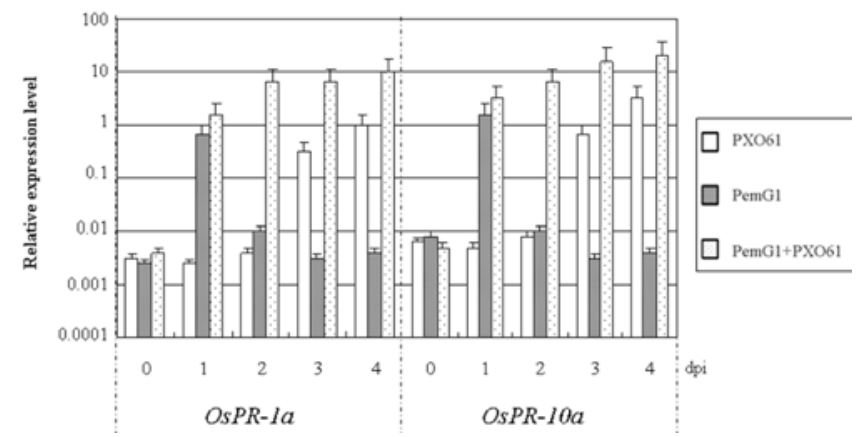

Fig. 2. Defense-related gene $O s P R-1 a$ and $O s P R-10 a$ expression induced by PemG1 treatment and pathogen inoculation in rice; dpi = days postinoculation. Rice defense-related gene expression induced by spraying with PemG1 solution or infection by pathogen Xanthomonas oryzae pv. oryzae POX61. Total RNA was extracted from leaves of five rice plants at $0,1,2,3$, and 4 days after inoculation with pathogen POX61. RNA samples were subjected to real-time reverse-transcription polymerase chain reaction with Osactin gene as the reference. Bars indicate mean \pm standard deviation.
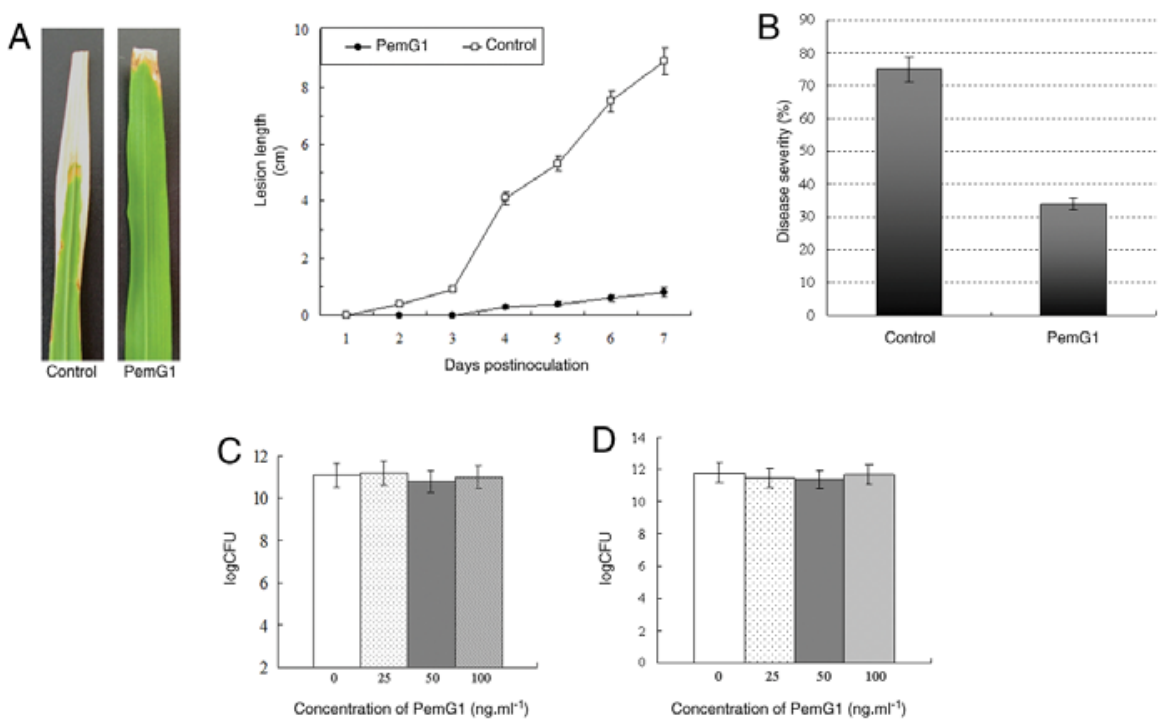

Fig. 1. Effects of PemG1 application on disease progress in plants. Plants were inoculated with each pathogen at $4 \mathrm{~h}$ after spraying with control (negative control protein in Tween 80 at $250 \mu \mathrm{g} / \mathrm{ml}$ ) or PemG1 (PemG1 at $50 \mu \mathrm{g} / \mathrm{liter}$ in Tween 80 at $250 \mu \mathrm{g} / \mathrm{ml}$ ) solutions. A, Rice plants ('Nakdong') were inoculated with rice bacterial leaf blight pathogen Xanthomonas oryzae pv. oryzae PXO61 $\left(1 \times 10^{8} \mathrm{CFU} / \mathrm{ml}\right) 4 \mathrm{~h}$ after spraying. Leaves were photographed 10 days postinoculation. The graph shows the lesions characteristic of rice bacterial leaf blight pathogen are suppressed in PemG1-treated rice plants. Values are mean \pm standard error $\left(n=10\right.$ plants). B, Arabidopsis Col-0 plants were inoculated with Pseudomonas syringae pv. tomato DC $3000 \mathrm{at} 5 \times 10^{8} \mathrm{CFU} / \mathrm{ml} 4 \mathrm{~h}$ after spraying. The graph shows the necrotic lesions normally caused on Arabidopsis ecotype Col-0 by pathogen P. syringae pv. tomato DC 3000 are suppressed in PemG1-treated plants. Values are means of disease severity with standard errors from 20 plants in a representative experiment that was repeated three times with similar results. Rating was performed 5 days after $P$. syringae pv. tomato DC 3000 inoculation. The effect of PemG1 on C, pathogen PXO61 and D, P. syringae pv. tomato DC 3000 growth. PXO61 and P. syringae pv. tomato DC 3000 were cultured in 50 ml of nutrient broth containing equal concentrations of PemG1 on a shaker at $150 \mathrm{rpm}$ and $28^{\circ} \mathrm{C}$ for 5 days. The cultures were started by adding $500 \mu \mathrm{l}$ of sterile distilled water or bacterial inoculum $\left(5 \times 10^{5} \mathrm{CFU}\right)$. The populations of bacteria in the suspension cultures were estimated by counting the CFU after appropriate dilution on peptone-Suc agar. Three replicates were performed for each PemG1 concentration. 
these genes at 2, 3, and 4 days after inoculation (Fig. 2). However, PemG1-treated plants that were not inoculated with the pathogen showed expression of these genes 1 days after treatment. That is, expression of the $P R$ genes was more rapid after PemG1 treatment than after pathogen inoculation. When PemG1-treated plants were inoculated with the pathogen, the expressions of the $P R$ genes were markedly higher than those in the pathogen-only or the PemG1-only treatments (Fig. 2). These results demonstrated that PemG1 induces transient expression of $P R$ genes in rice.

\section{Effects of PemG1 on disease resistance and systemic $P R$ gene expression.}

To determine whether the effects of PemG1 on disease resistance could spread from the site of treatment to other parts of the plant, PemG1 was sprayed on leaf four but not on leaf six of Nakdong rice plants. The leaves were harvested at 12 and $24 \mathrm{~h}$ after treatment. OSPR-1a gene expression was induced in both types of leaves from $12 \mathrm{~h}$ after treatment (Fig. 3A), indicating that the ability of PemG1 to induce $P R$ gene expression can be mobilized from the site of treatment to other parts of the plant.

To evaluate the effects of PemG1 on disease resistance throughout the plant, PemG1 was sprayed on leaf four but not on leaf six of rice plants (Nakdong), and then the plants were inoculated with the compatible bacterial leaf blight pathogen $X$. oryzae pv. oryzae PXO61. In control plants, typical blight symptoms clearly appeared at $48 \mathrm{~h}$ after inoculation and began to progress along the vascular system. Disease symptoms were not observed in leaves that had been treated with PemG1 or in leaves distant from the site of PemG1 treatment (Fig. 3B). These data indicated that the effects of PemG1 on disease resistance and $P R$ gene expression were mobilized systemically throughout the plant.

\section{Persistence of effects of PemG1 on disease resistance and $P R$ gene expression.}

To determine the duration of the resistance induced by PemG1 treatment, rice plants were treated with PemG1 and then inoculated with the blight pathogen after various periods of time. PemG1 was able to confer disease resistance for up to
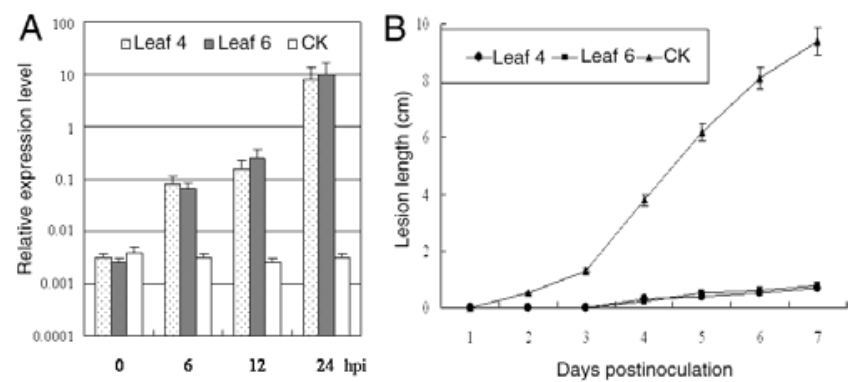

Fig. 3. Systemic effects of PemG1 on pathogenesis-related $(P R)$ gene expression and disease resistance. A, Systemic expression of $O S P R-1 a$ in rice induced by PemG1 treatment. For treatment rice, PemG1 was sprayed only on leaf 4 (PemG treated) but not leaf 6 (nontreated). Both leaf 4 and leaf 6 from mock treatment (negative control protein in Tween 80 at 250 $\mu \mathrm{g} / \mathrm{ml}$ ) rice plants were used as control (CK). Total RNA was extracted from both types of leaves from treatment group and from CK group of five plants at 6,12 , and $24 \mathrm{~h}$ after PemG1 treatment. RNA samples were subjected to real-time reverse-transcription polymerase chain reaction with Osactin gene as the reference. Bars indicate mean \pm standard deviation. B, Systemic effects of PemG1 application on disease development in rice. Rice ('Nakdong') plants were inoculated with pathogen Xanthomonas oryzae pv. oryzae POX61 $4 \mathrm{~h}$ after spraying with PemG1 solutions. Lesion size was determined at various times after treatment with or without PemG1. Values are mean \pm standard error $(n=10$ plants $)$.
28 days after treatment (Fig. 4A). When rice plants were inoculated with the blight pathogen at 7, 14, 21, and 28 days after PemG1 treatment, defense-related gene expression was detectable from 1 to 4 days after inoculation. However, disease protection and defense-related gene expression was not detectable at 35 days after PemG1 treatment. These results indicate that the ability of PemG1 to activate defense-related gene expression persists for at least 28 days (Fig. 4B).

\section{PemG1 induces an oxidative burst in rice.}

The oxidative burst has been implicated in hypersensitive cell death (Levine et al. 1994) and cellular defense responses (Alvarez et al. 1998). Therefore, we evaluated whether PemG1 affected the accumulation of reactive oxygen species (ROS) in rice plants. Treatment with only PemG1 $(50 \mathrm{ng} / \mathrm{ml})$ did not induce superoxide or hydrogen peroxide accumulation. However, challenge with PXO61 enhanced the accumulation of ROS in PemG1-pretreated rice leaves. After inoculation with PXO61, accumulation of hydrogen peroxide and superoxide at 12,24 , and $48 \mathrm{~h}$ postinoculation was greater in leaves that were pretreated with PemG1 than in those that were not (Fig. $5 \mathrm{~A}$ and $5 \mathrm{~B})$

\section{Systemic effects of PemG1 rely}

\section{on the $\mathrm{Ca}^{2+}$-dependent signaling pathway in rice.}

Among the earliest cellular events in plant-pathogen interactions, fluxes of ions (e.g., $\mathrm{Ca}^{2+}$ ) across membranes play important roles in the development of the HR (Blume et al. 2000; Romeis et al. 2001). To determine whether calcium signaling is involved in PemG1-induced resistance, we determined whether the effects of PemG1 could be eliminated by several calcium channel blockers: $\mathrm{LaCl} 3$, ethylene glycol-bis (2-aminoethylether)-N,N,N,N-tetraacetic acid (EGTA), 1,2-bis (2-aminophenoxy) ethane-N,N,N,N-tetraacetic acid (BAPTA), $\mathrm{N}$-(6-aminohexyl)-5-chloro-1-naphthalenesulfonamide (W7), and trifluoperazine (TFP) (Govrin and Levine 2000). We found that all the inhibitors do not affect the normal leaf growth. Infiltration of rice plants with $\mathrm{LaCl} 3$, EGTA,

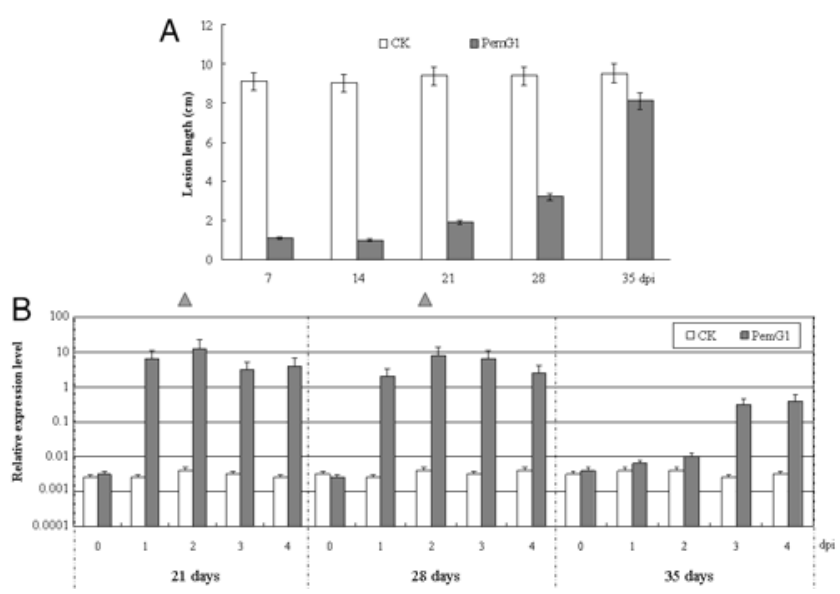

Fig. 4. Duration of PemG1 effects. A, Rice disease progress in mocktreated and PemG1-treated rice leaves following infection at 7, 14, 21, 28 , and 35 days after PemG1 treatment. Values are mean ( $n=10$ plants). White bars, mock-treated rice leaves (CK); black bars, PemG1-treated rice leaves (PemG1). B, Expression patterns of defense-related gene OsPR-1 $a$ in PemG1-treated (PemG1) and CK rice leaves inoculated with pathogen Xanthomonas oryzae pv. oryzae PXO61 at 21, 28, and 35 days after PemG1 treatment. Total RNA was extracted from leaves of five plants at $0,1,2,3$, and 4 days after pathogen inoculation. RNA samples were subjected to real-time reverse-transcription polymerase chain reaction with Osactin gene as the reference. Bars indicate mean \pm standard deviation. 
BAPTA, W-7, and TFP after PemG1 treatment prevented the accumulation of $O s P R-1 a$ gene transcripts (Fig. 5C). The sample treated only with PemG1 and the sample treated with $\mathrm{N}$-(6-aminohexyl)-1-naphthalenesulfonamide (W-5) (a W-7 analog which would not block the calcium channel in plants) after PemG1 inoculation detected an induced accumulation of $O s P R-1 a$ gene transcripts. These results indicated that a $\mathrm{Ca}^{2+}$-dependent signaling pathway was involved in the PemG1 effects in rice.

\section{PemG1-induced defense signaling is dependent} on the SA signaling pathway in Arabidopsis.

Several signaling pathways, including the SA pathway and the jasmonic acid and ethylene (JA/Et) pathway, are associated with the SAR response in Arabidopsis (Durrant and Dong
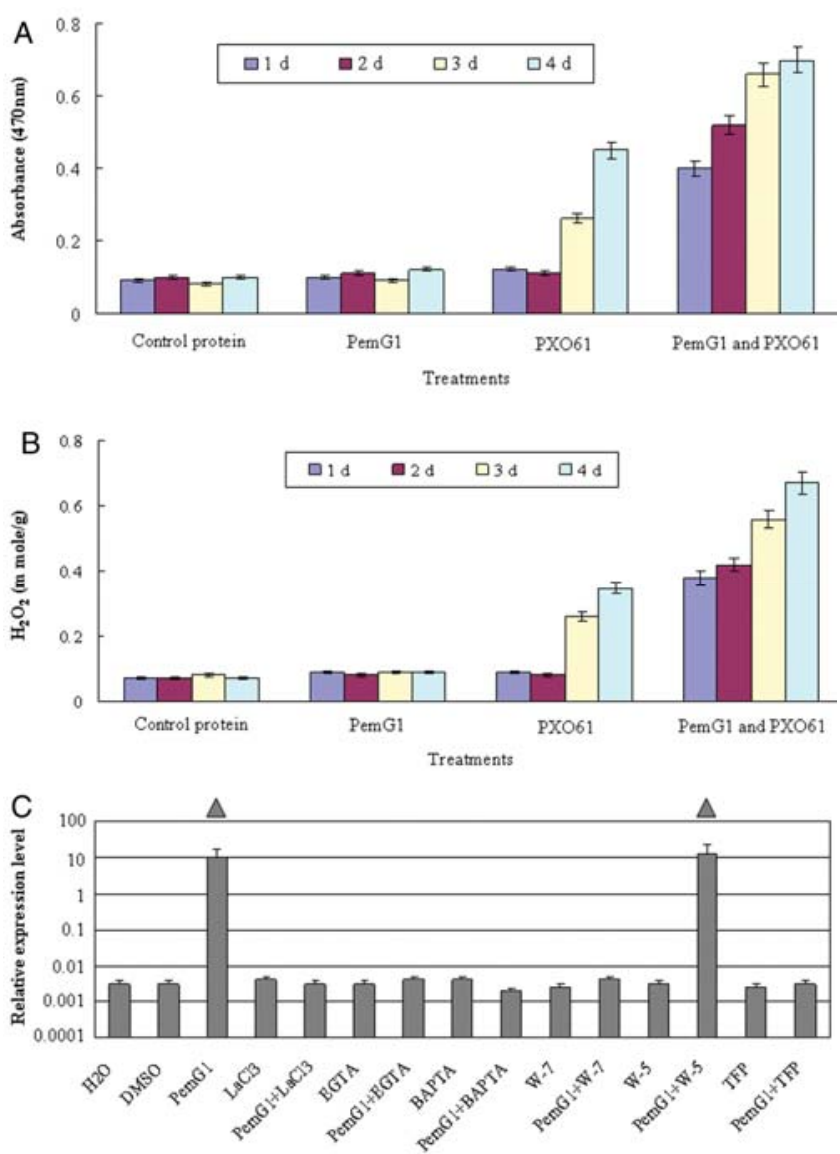

Fig. 5. Effects of PemG1 or pathogen inoculation on accumulation of A, $\mathrm{O}^{2-}$ and $\mathbf{B}$, hydrogen peroxide in rice. Data are averages from three experiments. Samples were treated with negative control protein in Tween 80 at $250 \mu \mathrm{g} / \mathrm{ml}$ only, PemG1 at $50 \mathrm{ng} / \mathrm{ml}$ in Tween 80 at $250 \mu \mathrm{g} / \mathrm{ml}$ only, or infected with pathogen Xanthomonas oryzae pv. oryzae PXO61 or with PXO61 after PemG1 treatment. Total protein was extracted from leaves of five plants harvested at 1,2,3, and 4 days after treatment. Values are mean \pm standard error ( $n=5$ plants). C, Infiltration of rice plants with calcium channel blockers $\mathrm{LaCl} 3$, ethylene glycol-bis (2-aminoethylether)$\mathrm{N}, \mathrm{N}, \mathrm{N}, \mathrm{N}$-tetraacetic acid (EGTA), 1,2-bis (2-aminophenoxy) ethane$\mathrm{N}, \mathrm{N}, \mathrm{N}, \mathrm{N}$-tetraacetic acid (BAPTA), N-(6-aminohexyl)-5-chloro-1-naphthalenesulfonamide (W-7), and trifluoperazine (TFP) suppressed PemG1induced $O S P R-1 a$ expression. Rice grown in the growth chamber to the seven-leaf stage was used for this analysis. Leaves infiltrated with $1 \mathrm{mM}$ different calcium channel blockers $4 \mathrm{~h}$ after spraying with PemG1 at 50 $\mathrm{ng} / \mathrm{ml}$. Leaves infiltrated only with distilled water, dimethyl sulfoxide, PemG1, or different chemicals $4 \mathrm{~h}$ after spraying with Tween 80 at 250 $\mu \mathrm{g} / \mathrm{ml}$ were used as control. Total RNA was extracted from both leaf 4 and leaf 6 of five plants $24 \mathrm{~h}$ after PemG1 treatment. RNA samples were subjected to real-time reverse-transcription polymerase chain reaction with Osactin gene as the reference. Bars indicate mean \pm standard deviation.
2004; Sels et al. 2008). To investigate which pathways were associated with the functions of PemG1, we evaluated the effects of PemG1 on expressions of AtPR-1, AtPR4, and AtPDF1.2 in Arabidopsis wild-type Col-0 and several Arabidopsis mutants (etr1, jarl-1, nprl, sid2-2, and NahG). Expressions of AtPR-1 were induced in wild-type Col-0, etrl (an altered perception of Et mutant), and jarl-1 (a mutant that displays reduced sensitivity to methyl JA) (Fig. 6A). However, PemG1 did not induce expressions of AtPR-1 in nprl (a mutant that does not accumulate PR-1 in response to SA), sid2-2 (an SA biosynthesis mutant that fails to accumulate SA in response to pathogens), and NahG (an Arabidopsis line expressing the bacterial NahG). In addition, no transcripts of AtPR4 and AtPDF1.2 (marker genes of JA/Et pathway) were detected in any of the PemG1-treated Arabidopsis plants (Fig. 6A).

Further, the ecotype Col- 0 and the above mutants were treated with PemG1 $4 \mathrm{~h}$ prior to inoculation with DC 3000. The $n p r l$, sid2-2, and NahG lines were not protected against
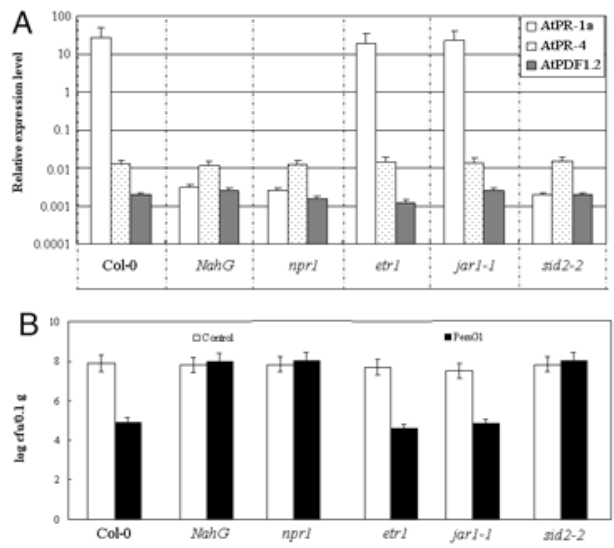

Fig. 6. Analysis of AtPR-1, AtPR-4, and AtPDF1.2 gene expression and quantification of resistance to Pseudomonas syringae pv. tomato DC 3000 infection following PemG1 treatment of Arabidopsis Col-0, NahG, nprl, etr 1, jarl-1, and sid2-2 plants. A, Transcription patterns of AtPR-1, AtPR4, and AtPDF1.2 in Arabidopsis Col-0, NahG, nprl, etrl, jar1-1, and sid22 after PemG1 treatments. Total RNA was extracted from leaves of five plants. RNA samples were subjected to real-time reverse-transcription polymerase chain reaction with Atactin gene as the reference. Bars indicate mean \pm standard deviation. B, Numbers of $P$. syringae pv. tomato DC 3000 in leaves of Arabidopsis Col-0 and signaling mutants (NahG, nprl, etrl, jarl-1, and sid2-2) treated with PemG1 $4 \mathrm{~h}$ prior to inoculation. Samples were collected from five plants 3 days after inoculation. White bars, control Arabidopsis leaves; black bars, PemG1-treated Arabidopsis leaves. Values are mean \pm standard error. All experiments were conducted independently three times, with three replicates.

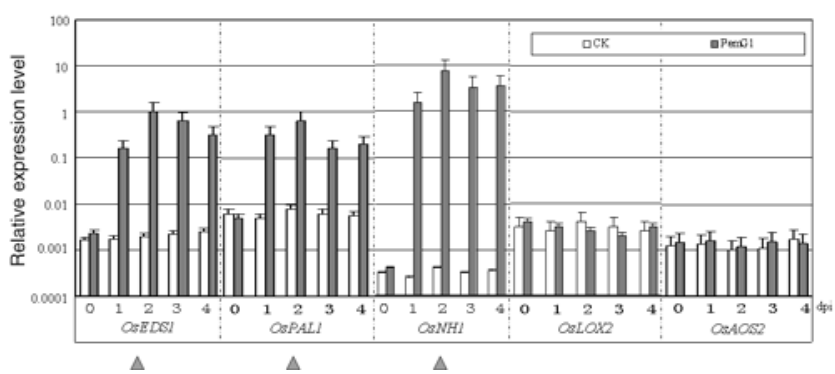

Fig. 7. Transcription patterns of OsEDS1, OsPAL1, OsNH1, OsLOX2, and OsAOS2 gene in PemG1-treated or nontreated rice as determined by realtime reverse-transcription polymerase chain reaction (qPCR). Rice plants were inoculated with blight pathogen PXO61 at 1,2, 3, and 4 days after PemG1 treatment. RNA samples were analyzed by qPCR. Relative expressions compared with that of control (Osactin gene) are shown. Transcript levels were determined at $0,1,2,3$, and 4 days after treatments of rice leaves. Bars indicate mean \pm standard deviation. 
the pathogen but the etrl and jarl lines were protected at levels similar to that in the wild-type Col-0 (Fig. 6B).

We also used real-time polymerase chain reaction (PCR) to analyze the expressions of SA- and JA-induced genes in PemG1-treated and control rice plants (Fig. 7). Rice plants were inoculated with the blight pathogen PXO61 at 1, 2, 3, and 4 days after PemG1 treatment. The expressions of the SA signal-related gene (OsEDS1, OsPAL1, and OsNH1) (Xie et al. 2011) were significantly induced in PemG1-treated rice. However, there was no difference in the expression of the JA pathway-related genes (OsLOX2 and OsAOS2) (Mei et al. 2006; Xie et al. 2011) between PemG1-treated and control rice plants (Fig. 7).

Taken together, these results indicate that the defense-related gene expression induced by PemG1 is dependent on the SA signaling pathway but not the JA/Et pathway in Arabidopsis. However, the role of the SA-dependent signaling pathway in the rice defense system remains to be elucidated because rice has high endogenous levels of SA.

\section{DISCUSSION}

In this study, we demonstrated that the PemG1 protein from the fungal pathogen $M$. grisea promotes the resistance of rice and Arabidopsis to bacterial infection (Fig. 1A and B). Several mechanisms by which proteins mediate plant disease protection have been described, including the direct inhibition of pathogen growth (Mansfield 2009; Molina et al. 1993; Stover and Driks 1999) and the induction of plant resistance to pathogen infection (Keller et al. 1999; Mansfield 2009; Mishra et al. 2009; Wei et al. 1992). Our results showed that PemG1 did not inhibit the growth of PXO61 and DC 3000 (Fig. 1C and D), implying that PemG1-mediated rice resistance to bacterial pathogen infection is due to enhanced plant resistance. Similar effects have been reported for other protein elicitors, including harpins (Wei et al. 1992), elicitins (Keller et al. 1999), and avirulence proteins (Mansfield 2009). Also, the amino acid sequence of PemG1 shows no identity or homology to other reported protein elicitors. Together, these findings indicate that PemG1 is a novel activator of plant SAR.

PemG1 treatments affected the expressions of defenserelated genes in rice (Fig. 2). In the compatible interaction between $X$. oryzae pv. oryzae and rice, transcripts of the tested defense-related and SAR-related genes began to accumulate relatively slowly after pathogen infection (after 2 days or longer). However, PemG1 treatment without pathogen inoculation induced the expression of these genes at 1 day after treatment. Although this was more rapid than the induction of expression after pathogen inoculation, the effect was transient, and transcripts levels fell to undetectable levels by 2 days after treatment (Fig. 2). The expressions of these genes were markedly higher in pathogen-inoculated-PemG1-treated plants than in both of other treatments (pathogen inoculation only or PemG1 treatment only). That is, PemG1 treatment alone triggered transient defense-related gene expression but PemG1treated plants that were infected with the pathogen showed rapid and strong expressions of these genes (Fig. 4). Similar SAR-inducing priming effects in plants have been reported after treatment with some pathogens (Zhang et al. 1998); chemicals, including SA (Narusaka et al. 1999), benzothiadiazole (Sauerborn et al. 2002), b-aminobutyric acid (Sauerborn et al. 2002), and vitamin B1 (Ahn et al. 2005, 2007); and proteins, including harpins (Wei et al. 1992) and elicitins (Keller et al. 1999).

When rice plants were treated with PemG1 and then inoculated with the pathogen, the "priming" effects of PemG1 persisted for several weeks (Fig. 4). To determine the duration of this priming effect, the intervals between PemG1 treatment and pathogen inoculation were extended to 28 days (Fig. 4). OSPR- $1 a$ transcripts were not detected at any time points after PemG1 treatment alone. After pathogen infection, however, OSPR-1 $a$ transcripts rapidly accumulated to high levels and disease protection was evident at $7,14,21$, and 28 days after PemG1 treatment. The above results indicate that PemG1 triggers enhanced defense responses in plants for at least 28 days, suggesting that it has potential applications as a protein elicitor for plant disease control.

Hydrogen peroxide is involved in hypersensitive cell death and also acts as a signaling molecule in cellular defense responses (Alvarez et al. 1998; Hu et al. 2003). In this study, we found that the levels of hydrogen peroxide and superoxide in leaves pretreated with PemG1 were significantly higher than those in leaves infected with PXO61 alone (Fig. 5). The low levels of hydrogen peroxide and superoxide in infected plants that had not been treated with PemG1 were correlated with poor resistance to the disease (Fig. 1) and low levels of $P R$ gene expression (Fig. 2). Hydrogen peroxide was also reported to play a key role in the SAR induced by 2,6-dichloroisonicotinic acid (Huckelhoven et al. 1999).

Among the earliest cellular events in plant-pathogen interactions, fluxes of ions, particularly $\mathrm{Ca}^{2+}$, across membranes play important roles in inducing resistance. Application of $\mathrm{LaCl} 3$, EGTA, BAPTA, W-7, and TFP, which blocks plasma-membrane-localized calcium channels, prevented PemG1-induced accumulation of OSPR-1a (Fig. 5C). These results indicated that the site of PemG1 action is upstream of the mobilization of $\mathrm{Ca}^{2+}$. This mechanism is consistent with those reported for fungal elicitors in plant cell cultures (El-Maarouf et al. 2001; Gelli et al. 1997), harpins in tobacco (El-Maarouf et al. 2001), and the chemical elicitor thiamine in plants (Ahn et al. 2005).

PemG1 treatment inhibited disease development through the activation of defense systems and the SAR response in plants. Several signaling pathways (SA, JA/Et, and so on) are involved in the SAR response. In Arabidopsis, PemG1 inhibited disease development in wild types and its mutants that are deficient in perception or signaling of SA, JA, or Et. PemG1-treated Col-0, etrl, and jarl lines showed high expressions of AtPR-1. In contrast, PemG1 did not trigger $P R$ gene expression in the npr1 lines (Fig. 6A). These results indicate that the defenserelated gene expression induced by PemG1 is dependent on the SA signaling pathway but not the JA/Et pathway. In rice, the expressions of the SA-signal-related gene (OsEDS1, OsPAL1, and OsNH1) were significantly induced in PemG1treated rice. However, there was no difference in the expression of the JA-pathway-related genes (OsLOX2 and OsAOS2) between PemG1-treated and control rice plants (Fig. 7). These results indicate that the defense-related gene expression induced by PemG1 is related the SA signaling pathway in rice. Similar dependence on the SA signaling pathway has also been reported for harpins (Wei et al. 1992) and elicitins (Keller et al. 1996; Romeis et al. 2001). However, the role of the SA-dependent signaling pathway in the rice defense system remains to be elucidated.

In summary, we isolated a novel protein elicitor, PemG1, from the fungal pathogen $M$. grisea. PemG1 confers disease resistance through priming several plant defense responses, leading to increased resistance to bacterial pathogens in plants. The resistance induced by PemG1 persists for at least 28 days, indicating that PemG1 is a good candidate as a plant defense activation agent. Although the precise action model involved in the induction of SAR by PemG1 remain unknown, our findings indicated that the SA- and calcium-dependent signaling pathways were involved in PemG1 effects. Our results provide a novel paradigm for screening protein elicitor from pathogen 
fungi to control plant disease, and the gene encoding PemG1 could be used as a functional gene in biopesticide or transgenic crops.

\section{MATERIALS AND METHODS}

Expression and purification of $M$. grisea PemG1 protein.

The PemG1 coding gene was amplified from the plasmid pMYE by PCR using a pair of primers (P1: 5'-ATGAATTCA CGATTCGTGCTACGGACGGT-3', and P2: 5'-ATGTCGACC AGGTACACCTTCACTTCCG-3') designed from the sequences of the PemG1 open reading frame. The amplified fragments were gel purified, digested with BamHI and NotI, and then cloned into the expression vector pGEX-6P-1 to yield plasmid pEMB0590. Then, the recombinant plasmid was transformed into $E$. coli $\mathrm{BL} 21(\mathrm{DE} 3)$ and positive clones were selected on Luria-Bertani (LB) plates containing ampicillin at $100 \mu \mathrm{g} / \mathrm{ml}$. The GST-PemG1 fusion protein was overexpressed in $E$. coli and purified on a GSTrap FF column. Then, the GST tag was cleaved from the fusion protein using PreScission Protease (Amersham Biosciences, Uppsala, Sweden). The purified PemG1 protein was quantified by the method of Bradford (1976) and then stored at $-20^{\circ} \mathrm{C}$ until further use. To confirm that there were no other $E$. coli derived elicitor or active contaminants, proteins were purified from $E$. coli carrying only the empty vector using the same methods as that of PemG1, and were used as the negative control.

\section{Preparation of chemicals.}

All chemicals were purchased from Sigma-Aldrich (St. Louis). Chemicals were dissolved in water or in appropriate solvents to make stock solutions and were sterilized by filtration. The EGTA ( $\mathrm{pH} \mathrm{7.5),} \mathrm{BAPTA,} \mathrm{LaCl} 3$, and TFP were dissolved in water to make a $100-\mathrm{mM}$ stock solution. Compound W-7 was dissolved in dimethyl sulfoxide to make a $100-\mathrm{mM}$ stock solution. Compound W-5 (N-[6-aminohexyl]-1-naphthalenesulfonamide) was dissolved in water to make a $5-\mathrm{mM}$ stock solution.

\section{Plant materials and treatments.}

Rice plants (Nakdong) were grown in a greenhouse under conditions described elsewhere (Kim et al. 2001). Seed of Arabidopsis (Arabidopsis thaliana ecotype Col-0) and Arabidopsis mutant lines (nprl, etrl, and jarl) were obtained from The Arabidopsis Information Resource. Arabidopsis plants were grown in a growth chamber at $22^{\circ} \mathrm{C}$ and 65 to $70 \%$ relative humidity, with $16 \mathrm{~h}$ of illumination daily. Protein treatments were applied to 1-month-old rice and Arabidopsis plants. The plants were sprayed with negative control protein at $50 \mathrm{ng} / \mathrm{ml}$ supplemented with Tween 80 (control) at $250 \mu \mathrm{g} / \mathrm{ml}$ or PemG1 at $50 \mathrm{ng} / \mathrm{ml}$ supplemented with Tween 80 at $250 \mu \mathrm{g} / \mathrm{ml}$ at $4 \mathrm{~h}$ prior to pathogen inoculation, unless stated otherwise.
The calcium ion inhibitors which block plasma membrane calcium channels was used in an aqueous solution. At $4 \mathrm{~h}$ after spraying of plants with PemG1 at $50 \mathrm{ng} / \mathrm{ml}$ supplemented with Tween 80 at $250 \mu \mathrm{g} / \mathrm{ml}, 1 \mathrm{mM}$ calcium ion inhibitors and control buffers was infiltrated into leaf 4 using a needleless syringe. The expression of the $O S P R-1$ gene in both leaf 4 and leaf 6 from treated plants was investigated at $24 \mathrm{~h}$ after PemG1 treatment by using real-time quantitative reverse-transcription PCR (qPCR) analysis.

\section{Pathogen maintenance and inoculation.}

The ability of PemG1 to control disease was determined by monitoring disease symptoms after pathogen inoculation. The bacterial leaf blight pathogen PXO61 was propagated and inoculated onto leaves of Nakdong rice as described by Kim and associates (2001). Plants were inoculated with PXO61 at $4 \mathrm{~h}$ after spraying with control (negative control protein at $50 \mathrm{ng} / \mathrm{ml}$ supplemented in Tween 80 at $250 \mu \mathrm{g} / \mathrm{ml}$ ) or PemG1 (PemG1 at $50 \mathrm{ng} / \mathrm{ml}$ in Tween 80 at $250 \mu \mathrm{g} / \mathrm{ml}$ ) solutions. The severity of the disease and the size of the lesions were assessed according to the rating scale of the International Rice Research Institute. In figures, values represent the mean \pm standard error of 10 plants. The inoculation of Arabidopsis with DC 3000 was conducted according to the methods described by Ahn and associates (2007). The severity of the disease was evaluated at 3 days after inoculation by determining the CFU in $0.1 \mathrm{~g}$ (fresh weight) of Arabidopsis leaves collected from five plants.

\section{Effect of PemG1 on pathogen growth.}

The PXO61 and DC 3000 were cultured in $50 \mathrm{ml}$ of nutrient broth containing different concentrations $(0,25,50$, and $100 \mathrm{ng} / \mathrm{ml}$ ) of PemG1 or control proteins on a shaker at 150 $\mathrm{rpm}$ and $28^{\circ} \mathrm{C}$. The cultures were started by adding $500 \mu \mathrm{l}$ of bacterial inoculums $\left(5 \times 10^{5} \mathrm{CFU}\right)$. After incubation for 1 to 5 days, the populations of bacteria in the suspension cultures were estimated by counting the CFU after appropriate dilution on peptone-Suc agar or LB agar plate. There replicates were performed for each pathogen and each PemG1 concentration.

\section{RNA extraction and expression analyses.}

Total RNA was extracted from inoculated or PemG1-treated plants and control plants using a total RNA isolation system (Promega Corp., Madison, WI, U.S.A.). Analyses of expressions of $P R$ genes were performed using qPCR, and the Osactin and Atactin gene was amplified as a quantitative control. The qPCR was conducted using iQ SYBR Green Supermix (Bio-Rad, Hercules, CA, U.S.A.) and an iCycler (BioRad) according to the manufacturer's instructions. At least three independent biological samples were used with speciWc primers for each individual gene (Table 1). The data were normalized by the value of actin genes, fold change in the expres-

Table 1. Primers used for real-time reverse-transcription polymerase chain reaction of pathogenesis-related and actin genes

\begin{tabular}{|c|c|c|c|}
\hline Genes & Forward primer $\left(5^{\prime}-3^{\prime}\right)$ & Reverse primer $\left(5^{\prime}-3^{\prime}\right)$ & Accession numbers \\
\hline OsPR-1a & GTATGCTATGCTACGTGTTTATGC & GCAAATACGGCTGACAGTACAG & AJ278436 \\
\hline OsPR-10a & GGCTTGGTCGACGACATTG & CAGGGTTAAGCTTCATGGTGTAGA & AF274850 \\
\hline OsLOX2 & AGATGAGGCGCGTGATGAC & CATGGAAGTCGAGCATGAACA & AK241395 \\
\hline OsAOS2 & TACCAGCCGTGCGCCACCAG & AGGACGGAGCTGGTTGAGTGG & AK061758 \\
\hline OsEDS1 & CCCCGCATACCACTTACT & TGTTGATGAAACCACTCCC & AK100117 \\
\hline OsPAL1 & GGTGTTCTGCGAGGTGATGA & AGGGTGGTGCTTCAGCTTGT & AK068993 \\
\hline OsNH1 & ATCTTGATGATGCGTTTGC & TCAGCTTGCTCCAGTATTTC & AK120715 \\
\hline$A t P R-4$ & ATCAGCGCTGCAAAGTCCTTC & GTGCTGTAGCCCATCCACCTG & At3g 12500 \\
\hline AtPDF 1.2 & TTGCTGCTTTCGACGCA & TGTCCCACTTGGCTTCTCG & At5g 44420 \\
\hline$A t P R-1$ & CGAAAGCTCAAGATAGCCCACA & TTCTGCGTAGCTCCGAGCATAG & At2g14610 \\
\hline Osactin & GAGTATGATGAGTCGGGTCCAG & ACACCAACAATCCCAAACAGAG & AK060893 \\
\hline Atactin & AGTGGTCGTACAACCGGTATTGT & GATGGCATGGAGGAAGAGAGAAAC & At3g18780 \\
\hline
\end{tabular}


sion level was calculated compared with that of healthy fourth leaves, and standard deviation values are shown.

Systemic translocation of PemG1-mediated defense signals.

To investigate the systemic translocation of defense responses induced by PemG1 in rice, the rice grown in leaf 7 which is 3 days after emerging was used for this analysis. Leaf 4 from a 35-day-old seedling was treated with PemG1 at $50 \mathrm{ng} / \mathrm{ml}$ or the control. The expression of the $O s P R-1$ gene in leaf 4 (PemG treated) and leaf 6 (nontreated) was investigated at 12 and $24 \mathrm{~h}$ after treatment in the presence of PXO61 inoculation by using qPCR analysis.

\section{Duration of protective effects of PemG1.}

To estimate the duration of the ability of PemG1 to induce resistance, the Nakdong rice grown to 30-day-old seedlings was used for this analysis. Leaf 4 was treated with PemG1 at $50 \mathrm{ng} / \mathrm{ml}$ or the control protein. The plants were then inoculated with conidial suspensions of PXO61 at 7, 14, 21, 28, and 35 days after spraying with PemG1. The progress of the disease was evaluated as described above. The expression of the $O s P R-1$ gene in leaf 4 from PemG-treated and control plants were investigated at $0,1,2,3$, and 4 days after PXO61 inoculation by using qPCR analysis.

\section{Quantitative determination of superoxide radicals and hydrogen peroxide.}

Superoxide and hydrogen peroxide were extracted from PemG1-treated and pathogen-inoculated rice leaves and quantified as described by Ahn and associates (2007). Samples were harvested from 20 plants in each experiment. These experiments were repeated at least three times.

\section{ACKNOWLEDGMENTS}

This study was supported by the National High Technology Research and Development Program (863) of China (2011AA10A203 and 2006AA02Z174), the National Basic Research Program (973) of China (2009CB118902 and 2011CB100706), the National Natural Science Foundation of China (30870066 and 31000020), the Genetically Modified Organisms Breeding Major Projects of China (2009ZX08009-032B), and the China 948 Program of Ministry of Agriculture (2011-G25) and Ministry of Forestry (2006-4-41).

\section{LITERATURE CITED}

Adam, A. L., Pike, S., Hoyos, M. E., Stone, J. M., Walker, J. C., and Novacky, A. 1997. Rapid and transient activation of a myelin basic protein kinase in tobacco leaves treated with harpin from Erwinia amylovora. Plant Physiol. 115:853-861.

Ahmad, M., Majerczak, D. R., Pike, S., Hoyos, M. E., Novacky, A., and Coplin, D. L. 2001. Biological activity of harpin produced by Pantoea stewartii subsp. stewartii. Mol. Plant-Microbe Interact. 14:12231234.

Ahn, I. P., Kim, S., and Lee, Y. H. 2005. Vitamin B1 functions as an activator of plant disease resistance. Plant Physiol. 138:1505-1515.

Ahn, I. P., Kim, S., Lee, Y. H., and Suh, S. C. 2007. Vitamin B1-induced priming is dependent on hydrogen peroxide and the NPR1 gene in Arabidopsis. Plant Physiol. 143:838-848.

Alfano, J. R., and Collmer, A. 1997. The type III (Hrp) secretion pathway of plant pathogenic bacteria: Trafficking harpins, Avr proteins, and death. J. Bacteriol. 179:5655-5662.

Allen, R. L., Bittner-Eddy, P. D., Grenville-Briggs, L. J., Meitz, J. C., Rehmany, A. P., Rose, L. E., and Beynon, J. L. 2004. Host-parasite coevolutionary conflict between Arabidopsis and downy mildew. Science 306:1957-1960.

Alvarez, M. E., Pennell, R. I., Meijer, P. J., Ishikawa, A., Dixon, R. A., and Lamb, C. 1998. Reactive oxygen intermediates mediate a systemic signal network in the establishment of plant immunity. Cell 92:773-784.

Blume, B., Nurnberger, T., Nass, N., and Scheel, D. 2000. Receptor-mediated increase in cytoplasmic free calcium required for activation of pathogen defense in parsley. Plant Cell 12:1425-1440.

Bradford, M. M. 1976. A rapid and sensitive method for the quantitation of microgram quantities of protein utilizing the principle of protein-dye binding. Anal. Biochem. 72:248-254.

Durrant, W. E., and Dong, X. 2004. Systemic acquired resistance. Annu. Rev. Phytopathol. 42:185-209.

El-Maarouf, H., Barny, M. A., Rona, J. P., and Bouteau, F. 2001. Harpin, a hypersensitive response elicitor from Erwinia amylovora, regulates ion channel activities in Arabidopsis thaliana suspension cells. FEBS (Fed. Eur. Biochem. Soc.) Lett. 497:82-84.

Gelli, A., Higgins, V. J., and Blumwald, E. 1997. Activation of plant plasma membrane $\mathrm{Ca}^{2+}$-permeable channels by race-specific fungal elicitors. Plant Physiol. 113:269-279.

Govrin, E. M., and Levine, A. 2000. The hypersensitive response facilitates plant infection by the necrotrophic pathogen Botrytis cinerea. Curr. Biol. 10:751-757.

He, S. Y., Huang, H. C., and Collmer, A. 1993. Pseudomonas syringae pv. syringae harpinPss: A protein that is secreted via the Hrp pathway and elicits the hypersensitive response in plants. Cell 73:1255-1266.

Hu, X., Bidney, D. L., Yalpani, N., Duvick, J. P., Crasta, O., Folkerts, O., and Lu, G. 2003. Overexpression of a gene encoding hydrogen peroxide-generating oxalate oxidase evokes defense responses in sunflower. Plant Physiol. 133:170-181.

Huckelhoven, R., Fodor, J., Preis, C., and Kogel, K. H. 1999. Hypersensitive cell death and papilla formation in barley attacked by the powdery mildew fungus are associated with hydrogen peroxide but not with salicylic acid accumulation. Plant Physiol. 119:1251-1260.

Hwang, S. H., Lee, I. A., Yie, S. W., and Hwang, D. J. 2008. Identification of an OsPR10a promoter region responsive to salicylic acid. Planta 227:1141-1150.

Jiang, R. H., Tyler, B. M., Whisson, S. C., Hardham, A. R., and Govers, F. 2006. Ancient origin of elicitin gene clusters in Phytophthora genomes. Mol. Biol. Evol. 23:338-351.

Keller, H., Blein, J. P., Bonnet, P., and Ricci, P. 1996. Physiological and molecular characteristics of elicitin-induced systemic acquired resistance in tobacco. Plant Physiol. 110:365-376.

Keller, H., Pamboukdjian, N., Ponchet, M., Poupet, A., Delon, R., Verrier, J. L., Roby, D., and Ricci, P. 1999. Pathogen-induced elicitin production in transgenic tobacco generates a hypersensitive response and nonspecific disease resistance. Plant Cell 11:223-235.

Kim, S., Ahn, I. P., Park, C. H., Park, S. G., Park, S. Y., Jwa, N. S., and Lee, Y. H. 2001. Molecular characterization of the cDNA encoding an acidic isoform of PR-1 protein in rice. Mol. Cells 11:115-121.

Kvitko, B. H., Ramos, A. R., Morello, J. E., Oh, H. S., and Collmer, A. 2007. Identification of harpins in Pseudomonas syringae pv. tomato DC3000, which are functionally similar to HrpK1 in promoting translocation of type III secretion system effectors. J. Bacteriol. 189:80598072 .

Levine, A., Tenhaken, R., Dixon, R., and Lamb, C. 1994. H2O2 from the oxidative burst orchestrates the plant hypersensitive disease resistance response. Cell 79:583-593.

Mansfield, J. W. 2009. From bacterial avirulence genes to effector functions via the hrp delivery system: An overview of 25 years of progress in our understanding of plant innate immunity. Mol. Plant Pathol. 10:721-734.

Mei, C., Qi, M., Sheng, G., and Yang, Y. 2006. Inducible overexpression of a rice allene oxide synthase gene increases the endogenous jasmonic acid level, PR gene expression, and host resistance to fungal infection. Mol. Plant-Microbe Interact. 19:1127-1137.

Mishra, A. K., Sharma, K., and Misra, R. S. 2009. Purification and characterization of elicitor protein from Phytophthora colocasiae and basic resistance in Colocasia esculenta. Microbiol. Res. 164:688-693.

Mitsuhara, I., Iwai, T., Seo, S., Yanagawa, Y., Kawahigasi, H., Hirose, S., Ohkawa, Y., and Ohashi, Y. 2008. Characteristic expression of twelve rice PR1 family genes in response to pathogen infection, wounding, and defense-related signal compounds (121/180). Mol. Genet. Genomics 279:415-427.

Molina, A., Segura, A., and Garcia-Olmedo, F. 1993. Lipid transfer proteins (nsLTPs) from barley and maize leaves are potent inhibitors of bacterial and fungal plant pathogens. FEBS (Fed. Eur. Biochem. Soc.) Lett. 316:119-122.

Narusaka, Y., Narusaka, M., Horio, T., and Ishii, H. 1999. Comparison of local and systemic induction of acquired disease resistance in cucumber plants treated with benzothiadiazoles or salicylic acid. Plant Cell Physiol. 40:388-395.

Oh, J., Kim, J. G., Jeon, E., Yoo, C. H., Moon, J. S., Rhee, S., and Hwang, I. 2007. Amyloidogenesis of type III-dependent harpins from plant pathogenic bacteria. J. Biol. Chem. 282:13601-13609.

Osman, H., Mikes, V., Milat, M. L., Ponchet, M., Marion, D., Prange, T., Maume, B. F., Vauthrin, S., and Blein, J. P. 2001a. Fatty acids bind to 
the fungal elicitor cryptogein and compete with sterols. FEBS (Fed Eur. Biochem. Soc.) Lett. 489:55-58.

Osman, H., Vauthrin, S., Mikes, V., Milat, M. L., Panabieres, F., Marais, A., Brunie, S., Maume, B., Ponchet, M., and Blein, J. P. 2001b. Mediation of elicitin activity on tobacco is assumed by elicitin-sterol complexes. Mol. Biol. Cell 12:2825-2834.

Qiu, D., Mao, J., Yang, X., and Zeng, H. 2009. Expression of an elicitorencoding gene from Magnaporthe grisea enhances resistance against blast disease in transgenic rice. Plant Cell Rep. 28:925-933.

Romeis, T., Ludwig, A. A., Martin, R., and Jones, J. D. 2001. Calcium-dependent protein kinases play an essential role in a plant defence response. EMBO (Eur. Mol. Biol. Organ.) J. 20:5556-5567.

Rowland, O., Ludwig, A. A., Merrick, C. J., Baillieul, F., Tracy, F. E., Durrant, W. E., Fritz-Laylin, L., Nekrasov, V., Sjolander, K., Yoshioka, H., and Jones, J. D. 2005. Functional analysis of Avr9/Cf-9 rapidly elicited genes identifies a protein kinase, ACIK1, that is essential for full Cf-9-dependent disease resistance in tomato. Plant Cell 17:295310 .

Sauerborn, J., Buschmann, H., Ghiasi, K. G., and Kogel, K. H. 2002. Benzothiadiazole activates resistance in sunflower (Helianthus annuиs) to the root-parasitic weed Orobanche cuman. Phytopathology 92:59-64.

Sels, J., Mathys, J., De Coninck, B. M., Cammue, B. P., and De Bolle, M. F. 2008. Plant pathogenesis-related (PR) proteins: A focus on PR peptides. Plant Physiol. Biochem. 46:941-950.

Shao, M., Wang, J., Dean, R. A., Lin, Y., Gao, X., and Hu, S. 2008. Expression of a harpin-encoding gene in rice confers durable nonspecific resistance to Magnaporthe grisea. Plant Biotechnol. J. 6:73-81.

Shen, Q. H., Zhou, F., Bieri, S., Haizel, T., Shirasu, K., and SchulzeLefert, P. 2003. Recognition specificity and RAR1/SGT1 dependence in barley Mla disease resistance genes to the powdery mildew fungus Plant Cell 15:732-744.

Stover, A. G., and Driks, A. 1999. Secretion, localization, and antibacterial activity of TasA, a Bacillus subtilis spore-associated protein. J. Bacteriol. 181:1664-1672.

Vauthrin, S., Mikes, V., Milat, M. L., Ponchet, M., Maume, B., Osman, H., and Blein, J. P. 1999. Elicitins trap and transfer sterols from micelles, liposomes and plant plasma membranes. Biochim. Biophys. Acta 1419:335-342.

Vlot, A. C., Klessig, D. F., and Park, S. W. 2008. Systemic acquired resistance: The elusive signal(s). Curr. Opin. Plant Biol. 11:436-442.

Wei, Z. M., Laby, R. J., Zumoff, C. H., Bauer, D. W., He, S. Y., Collmer, A., and Beer, S. V. 1992. Harpin, elicitor of the hypersensitive response produced by the plant pathogen Erwinia amylovora. Science 257:85-88.

Xie, X. Z., Xue, Y. J., Zhou, J. J., Zhang, B., Chang, H., and Takano, M. 2011. Phytochromes regulate SA and JA signaling pathways in rice and are required for developmentally controlled resistance to Magnaporthe grisea. Mol. Plant. 4:688-696.

Yousef, L. F., Yousef, A. F., Mymryk, J. S., Dick, W. A., and Dick, R. P. 2009. Stigmasterol and cholesterol regulate the expression of elicitin genes in Phytophthora sojae. J. Chem. Ecol. 35:824-832.

Yu, L. M. 1995. Elicitins from Phytophthora and basic resistance in tobacco. Proc. Natl. Acad. Sci. U.S.A. 92:4088-4094.

Zhang, W., Han, D. Y., Dick, W. A., Davis, K. R., and Hoitink, H. A. 1998. Compost and compost water extract-induced systemic acquired resistance in cucumber and Arabidopsis. Phytopathology 88:450-455.

Zhang, Y., Yang, X., Liu, Q., Qiu, D., Zeng, H., Yuan, J., and Mao, J. 2010. Purification of novel protein elicitor from Botrytis cinerea that induces disease resistance and drought tolerance in plants. Microbiol. Res. $165: 142-151$

A modification to the Acknowledgment section to recognize a 2011 Chinese 973 research grant was published on September 16, 2011. 